\title{
KONSEP DAN PERAN DATA BASE DALAM SIM
}

\author{
SUGANDA KRIS SAPUTRA \\ 165100056
}

Fakultas Komputer, 448757267

sugandakrissaputra.studen@umitra.ac.id

\begin{abstract}
Database adalah suatu kumpulan data terhubung (interrelated data) yang disimpan secara bersama-sama pada suatu media, tanpa mengatap satu sama lain atau tidak perlu suatu kerangkapan data (controlled redundancy) dengan cara tertentu sehingga mudah digunakan atau ditampilkan kembali; dapat digunakan oleh satu atau lebih program aplikasi secara optimal; data disimpan tanpa mengalami ketergantungan pada program yang akan menggunakannya; data disimpan sedemikian rupa sehingga penambahan, pengambilan, dan modifikasi dapat dilakukan dengan mudah dan terkontrol . Keberhasilan suatu system informasi manajemen (SIM) sangat dipengaruhi oleh system database yang merupakan salah satu elemen penyusun system tersebut. Semakin lengkap, akurat, dan mudah dalam menampilakan kembali data-data yang termuat dalam system database, akan semakin meningkatkan kualitas SIM tersebut. Oleh karena itu sangatlah penting menyusun system database yang baik, yang mampu memenuhi kebutuhan data atau informasi pemakainya.
\end{abstract}

Kata Kunci : konsep dan peran data base dalam SIM . 


\section{A. INTRODUCTION}

Database adalah suatu kumpulan data terhubung (interrelated data) yang disimpan secara bersama-sama pada suatu media, tanpa mengatap satu sama lain atau tidak perlu suatu kerangkapan data (controlled redundancy) dengan cara tertentu sehingga mudah digunakan atau ditampilkan kembali; dapat digunakan oleh satu atau lebih program aplikasi secara optimal; data disimpan tanpa mengalami ketergantungan pada program yang akan menggunakannya; data disimpan sedemikian rupa sehingga penambahan, pengambilan, dan modifikasi dapat dilakukan dengan mudah dan terkontrol

\section{B. CONCLUSION}

Keberhasilan suatu system informasi manajemen (SIM) sangat dipengaruhi oleh system database yang merupakan salah satu elemen penyusun system tersebut. Semakin lengkap, akurat, dan mudah dalam menampilakan kembali datadata yang termuat dalam system database, akan semakin meningkatkan kualitas SIM tersebut. Oleh karena itu sangatlah penting menyusun system database yang baik, yang mampu memenuhi kebutuhan data atau informasi pemakainya.

\section{ACKNOWLEDGEMENT} University Of Mitra Indonesia 


\section{REFERENCE (Based ISO 690 )}

[2] A. S. Putra, O. M. Febriani, And B. Bachry, "Implementasi Genetic Fuzzy System Untuk Mengidentifikasi Hasil Curian Kendaraan Bermotor Di Polda Lampung," J. Sist. Inf. Dan Manaj. Basis Data, Vol. 1, No. 1, Pp. 21-30, 2018.

[3] O. M. Febriani And A. S. Putra, "Sistem Informasi Monitoring Inventori Barang Pada Balai Riset Standardisasi Industri Bandar Lampung," J. Inform.,

Vol. 13, No. 1, Pp. 90-98, 2014.

[4] Putra, Arie Setya. "2018 Artikel Struktur Data, Audit Dan Jaringan Komputer." (2018).

[5] Putra, A. S. (2018, July 17). Paperplain Fundamental Create Application With Borland Delphi 7.0 University Of Mitra Indonesia. Retrieved From Osf.Io/Pbrn9.

\section{E. REFERENCE(Based APA $)$}

Putra, A. S., Aryanti, D. R., \& Hartati, I. (2018, November). Metode SAW (Simple Additive Weighting) sebagai Sistem Pendukung Keputusan Guru Berprestasi (Studi Kasus: SMK Global Surya). In Prosiding Seminar Nasional Darmajaya (Vol. 1, No. 1, pp. 85-97).

Sari, D. P., Febriani, O. M., \& Putra, A. S. (2018, November). Perancangan Sistem Informasi SDM Berprestasi pada SD Global Surya. In Prosiding Seminar Nasional Darmajaya (Vol. 1, No. 1, pp. 289-294).

Putra, A. S. (2018). Paperplain: Execution Fundamental Create Application With Borland Delphi 7.0 University Of Mitra Indonesia.

Putra, A. S., Sukri, H., \& Zuhri, K. Sistem Monitoring Realtime Jaringan Irigasi Desa (JIDES) Dengan Konsep 
Jaringan Sensor Nirkabel. IJEIS (Indonesian Journal of Electronics and Instrumentation Systems), 8(2), 221232.

Darmawan, A., Yuliawati, D., Marcella, O., \& Firmandala, R. (2016). Sistem Absensi dan Pelaporan Berbasis Fingerprint dan SMS Gateway. EXPLORE, 7(1).

Febriani, O. M., Wahyuni, T., \& Yusuf, S. (2017). DESIGN OF WEBSITE-BASED INFORMATION SYSTEM FOR EDOCUMENT ADMINISTRASI IN THE COMMUNITY SERVICE UNIT (A Case Study at Rajabasa District). INTERNATIONAL JOURNAL OF COMPUTERS \& TECHNOLOGY, 16(7), 7010-7020.

Febriani, O. M., \& Wahyuni, T. (2017, October). PERANCANGAN SISTEM E-DOCUMENT ADMINISTRASI LOGBOOK PENELITIAN PADA UNIT LAYANAN DI BANDAR LAMPUNG. In Prosiding Seminar Nasional Darmajaya (Vol. 1, No. 1, pp. 187-194).

Febriani, O. M., \& Permadi, A. B. (2017). Implementasi Sistem Aplikasi Data Bimbingan dan Pelanggaran Siswa pada Sekolah Menengah Atas di Lampung Tengah dengan Metode Analisis dan Desain Sistem Terdistribusi (SSAD). EXPERT, 7(1).

Febriani, O. M., \& Ambarwati, L. (2015). PERANCANGAN APLIKASI PENGOLAHAN DATA PENJUALAN UKM KELANTING KHAS TELO DESA SIDOHARJO

\section{KECAMATAN JATI AGUNG KABUPATEN LAMPUNG SELATAN. Jurnal Teknologi Informasi dan Bisnis Pengabdian Masyarakat Darmajaya, 1(1), 77-95.}

Febriani, O. M. (2015). Rancang Bangun Aplikasi Ecommercemenggunakan Freewebstore pada UKM Kelanting di Desa Sidoharjo Lampung Selatan. Prosiding Sembistek 2014, 1(02), 446-458. 